\title{
ANÁLISE DO PODER COMO ÊXITO NO PROCESSO DE COMUNICAÇÃO.
}

\section{ANALYSIS OF POWER AS A SUCCESS IN THE COMMUNICATION PROCESS.}

\section{Carlos Augusto de Oliveira Diniz ${ }^{1}$}

Resumo: O presente trabalho visa analisar o poder e seus aspectos objetivos como efetividade e exercício dentro de um contexto relacional de comunicação. Poder não poder ser visto, tocado, armazenado. Por isso ele só será percebido nas relações sociais e assim ele é percebido quando o processo de comunicação é exitoso. Para tanto utilizamos o método dedutivo em revisão bibliográfica. O objetivo geral é analisar o poder como capacidade de influenciar decisões, o específico é demonstrar que no Brasil em 2016 tivemos o golpe como exemplo de exercício de poder.

Palavras-Chave: Poder; Comunicação; Mensuração do Poder; Significante; Significado.

Abstract: This paper aims to analyze power and its objective aspects as effectiveness and exercise within a relational context of communication. Power can not be seen, touched, stored. Hence it will only be perceived in social relations and thus it is perceived when the communication process is successful. For this we use the deductive method in bibliographic review. The general objective is to analyze power as a capacity to influence decisions, the specific thing is to demonstrate that in Brazil in 2016 we had the coup as an example of the exercise of power.

Keywords: Power; Communication; Measurement of Power; Significant; Meaning.

\section{Introdução.}

A abordagem que será feita no presente trabalho se fundamenta no poder e seus aspectos objetivos, principalmente aqueles ligados ao seu exercício e sua efetividade, pois o termo é muito difundido no meio social, porém por vezes a sua aplicação ou análise conduz a uma compreensão de que geralmente quando este termo é utilizado pouco se reflete para sua essência.

\footnotetext{
${ }^{1}$ Doutor em Direito pela Pontifícia Universidade Católica de São Paulo (PUC-SP), Área de Concentração: Efetividade do Direito na linha de pesquisa: Ética, Linguagem e Justiça. Professor da Carreira de Magistério Superior do Curso de Direito da Universidade Federal de Goiás (UFG) - Regional Jataí-GO. Coordena o Projeto de Pesquisa "Poder, Estado e Capitalismo: Impactos no Processo de Construção do Direito (PI03572-2019)". Lattes: http://lattes.cnpq.br/3127802813505867 - E-mail: carlosaugustodiniz@hotmail.com; Endereço: Universidade Federal de Goiás - Regional Jataí / Campus Jatobá / Prédio do Curso de Direito / Gabinete 24. BR 364, Km 195, nº 3800, CEP: 75801-615, Jataí-GO.
} 
Então, percebemos que o significante poder possui uma compreensão vasta, complexa, e por vezes contraditória, devido ao significado que esse termo possui, ou seja, não raro se diz que alguém tem poder e com isso passa-se a ideia de que o poder seja um substantivo capaz de estar com alguém ou mesmo em algum lugar, porém o que realmente se constatou é que o poder é verbo, ou seja, aproxima-se da ação humana.

Dessa forma, o presente trabalho se propõe a analisar como esta ação é capaz de produzir resultados, efeitos práticos, ou seja, como é possível o exercício do poder? De inicio sabemos que não há como falar em poder sem que se esteja em sociedade, ou seja, não existe poder, mas relações de poder, pois não há como o indivíduo exercer poder em si mesmo é preciso ressaltar seu aspecto relacional. Outro aspecto é que nesse processo de relação (emissor-receptor) a capacidade de sucesso em comunicar poder é que demonstrará quem exerce poder e quem molda suas ações para atender a comunicação de poder recebida do emissor.

Neste sentido no o desenvolvimento do presente trabalho inicia procurando demonstrar como se dá a comunicação de poder onde utilizamos ensinamentos de Márcio Pugliesi, depois fizemos uma análise fundada na obra de Jessé de Souza sobre o papel da mídia nesse processo de comunicação de poder no Brasil em 2016, ao final analisamos com base em Pierre Bourdieu e sua análise sobre o simbolismo e seu papel nesse processo de comunicação. Ao final chegamos a uma conclusão que poderá ser vista ao final do presente trabalho.

Ressalte-se que o presente trabalho utilizamos o método dedutivo em uma revisão bibliográfica, como objetivo geral tem-se analisar o poder como capacidade de influenciar decisões, já como objetivo específico é demonstrar que no Brasil em 2016 tivemos o golpe como exemplo sucesso do processo de comunicação de poder.

\section{Comunicação de poder.}

Iniciaremos com uma passagem da literatura universal. Trata-se de trecho de Dom Quixote de Miguel de Cervantes onde destacamos o conflito entre duas formas diversas de percepção do mundo. Vejamos:

Nisso, avistaram trinta ou quarenta moinhos de vento que há naquele campo. Mal dom Quixote os viu, disse a seu escudeiro:

- O acaso vai guiando nossas coisas melhor do que poderíamos desejar: olha lá, amigo Sancho Pança, onde estão uns trinta gigantes monstruosos, com quem penso

Rev. de Sociologia, Antropologia E Cultura Jurídica | e-ISSN: 2526-0251 | Goiânia| v. 5 | n. 1 | p. 23-42 | Jan/Jun. 2019 
travar batalha e a todos tirar as vidas. Com os despojos deles começaremos a enriquecer, que esta guerra é boa, e grande serviço presta a Deus quem varre da face da terra semente tão maligna.

— Que gigantes? - disse Sancho Pança.

- Aqueles ali, de braços compridos — respondeu o amo. - Alguns costumam ter braços de quase duas léguas.

- Olhe vossa mercê — respondeu Sancho —, aqueles que estão ali não são gigantes, mas moinhos de vento, e o que neles parecem braços são as pás, que, rodadas pelo vento, fazem trabalhar as mós.

- Bem se vê — respondeu dom Quixote - que não és versado em aventuras: eles são gigantes. E, se tens medo, some-te daqui e fica rezando enquanto isso, porque vou travar com eles uma batalha feroz e desigual. E, dizendo isso, esporeou seu cavalo Rocinante, sem ligar para os gritos de seu escudeiro Sancho, avisando-o de que sem dúvida nenhuma eram moinhos de vento e não gigantes aqueles que ia atacar. Ele ia tão convencido de que eram gigantes que nem ouvia seu escudeiro Sancho nem conseguia ver o que eram, embora já estivesse bem perto; pelo contrário, ia dizendo aos brados:

- Não fujais, covardes e vis criaturas, que apenas um cavaleiro vos ataca. Nesse instante o vento soprou um pouco, e as grandes pás começaram a se mover; vendo isso, dom Quixote disse:

- Ainda que movais mais braços que os do gigante Briareu, haveis de me pagar. Dizendo isso e se encomendando de todo coração a sua senhora Dulcineia, pedindolhe que o socorresse em tamanho aperto, bem protegido pela rodela, com a lança em riste, arremeteu a toda brida com Rocinante e investiu no primeiro moinho que encontrou pela frente. Quando deu uma lançada na pá, girou-a com tanta fúria o vento que fez a lança em pedaços, levando junto o cavalo e o cavaleiro, que foi rolando todo desconjuntado pelo campo. Sancho Pança correu para socorrê-lo, a galope em seu burro, mas ao chegar achou que ele não podia se mexer, tamanho fora o tombo que Rocinante dera com ele. ${ }^{2}$

Tal passagem intriga pelo antagonismo de duas visões, uma a de Dom Quixote que percebe que está diante de enormes gigantes e que sua missão de bravura recomenda o combate enérgico, a outra a visão de Sancho Pança, o fiel escudeiro, cuja percepção permite que avise a seu amo que não são gigantes, mas moinhos de vento.

Quem sofreu mais? Dom Quixote que potencializou o objeto e se chocou com ele de modo abrupto? Ou Sancho Pança que viu o objeto de modo sóbrio em sua real magnitude, mas que foi incapaz de conduzir a ação do amo para evitar o choque?

A comunicação é a forma pela qual se leva uma informação detida/dominada por uma fonte ao destinatário num processo de disseminação. O termo comunicação pode ser separado em duas frações, uma que se refere à comunicação de massa e ai encontram-se os meios de comunicação (radio, televisão, jornal, internet), e um segundo que está mais às comunicações

${ }^{2}$ CERVANTES, Miguel de. Dom Quixote de la Mancha. Tradução e Notas Ernani Ssó. Volume 1 Introdução de Jonh Rutherford. Volume 2 Posfácios de Jorge Luis Borges e Ricardo Piglia. São Paulo: Companhia das Letras, 2012. p. 65. 
interindividuais que são diretas e interativas a todas as situações cotidianas (sociais, profissionais, familiares, jurídicas, etc.). ${ }^{3}$

O modelo de comunicação quando explicado de modo técnico pode ser assim representado: FONTE > mensagem > EMISSOR > sinal > ( fonte de ruído) $>$ sinal recebido $>$ RECEPTOR > mensagem > DESTINATÁRIO.

\begin{abstract}
A fonte é o local de geração da mensagem. A mensagem é o conteúdo a ser transmitido (informação, representações, conceitos etc.) O emissor é o instrumento que transforma a mensagem em sinal, necessitando de um sistema de codificação adequado ao canal de transmissão escolhido. O canal é o suporte físico que permite a transmissão do sinal do emissor ao receptor. O receptor, graças à decodificação, restitui ao destinatário a mensagem. O rú́do é todo fenômeno parasita que altera a comunicação. Sendo este esquema interessante para o ramo técnico, Shannon não deixou de falar nos transdutores, ou codificadores/decodificadores ligados em paralelo à saída e entrada do sinal. Por seu turno, o sinal não deixa de constituir uma recodificação da mensagem que, por sua vez, corresponde a sinais já codificados. Ou seja, o sinal corresponde a uma verdadeira mensagem que, por sua vez, se pode ligar a alguma coisa ou estado de coisas do mundo, a um contexto ou referente. Finalmente, tanto a fonte e o transmissor, como o receptor e o destino, correspondem a unidades (quase sempre: sistemas) interligadas, se considerarmos o transmissor e o receptor como subsistemas, respectivamente, da fonte e do destino. Assim, por exemplo, uma pessoa pode ser tanto a fonte como o destino das mensagens verbais, sendo o seu aparelho fonador o subsistema transmissor, e o aparelho auditivo o subsistema receptor. ${ }^{4}$
\end{abstract}

O canal apesar de não ter aparecido no esquema acima citado apresenta-se como a forma competente para levar aquele esquema de comunicação. O o canal/forma será plural, existindo diversas possibilidades nas quais a forma/canal irá surgir, mas sempre trará a mensagem conforme o esquema citado anteriormente. A forma aqui é importante, mas não imprescindível, mesmo porque existem várias formas para levar uma mensagem de poder.

Importante é destacar que nesse esquema de comunicação é quase impossível que ocorra uma transmissão integral da mensagem, de modo que será comum que neste processo ocorra algum tipo de perda. Evidentemente o sucesso comunicativo esta diretamente dependente da qualidade da transmissão, do tipo de canal escolhido, e também das interferências às quais a comunicação está sujeita. ${ }^{5}$

E essas interferências são o que se definiu no esquema como sendo o ruído (o barulho da sala de aula, o latido do cão durante o horário eleitoral, o avião que sobrevoa a residência quando se estuda). O ruído é a diferença entre a informação emitida e a recebida. ${ }^{6}$

\footnotetext{
${ }^{3}$ PUGLIESI, Marcio. Teoria do Direito. 2 ed. São Paulo: Saraiva, 2009.
}

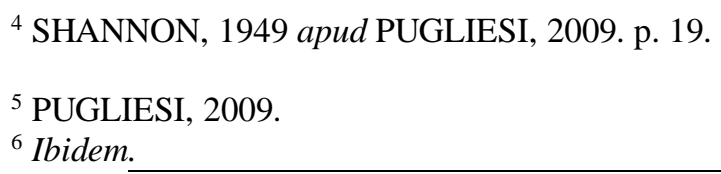




\begin{abstract}
A noção de ruído pode ainda ser aplicada à comunicação inter-pessoal. Uma coisa é o que se quer dizer, outra é o que se diz, outra o que se ouve e outra, finalmente, o que o ouvinte se lembra de ter ouvido. Em cada uma destas transmissões perde-se inevitavelmente informação e um exemplo dramático dessa perda encontra-se nas diferentes traduções de texto, em particular, a tradução a partir da tradução de original vertido em língua de difícil conhecimento, como na Bíblia, por exemplo ou, o que é ainda pior, nos testemunhos de oitiva, aquele em que a testemunha depõe porque ouviu algum outro dizer. ${ }^{7}$
\end{abstract}

Um exemplo para tentar reforçar o entendimento pode ser o seguinte. Pense no pronunciamento de um orador que se dirige a três pessoas diferentes: Parabéns você só chegou ao topo por conta de um golpe! Desta fala surgirão diversas interpretações. $1^{\mathrm{a}}$ - Um judoca olímpico pensará que a fala se dirige a ele e faz menção a uma medalha de ouro conquistada na Olimpíada em 2016. $2^{\text {a }}$ - Já àquele que ascendeu à presidência de uma empresa terá certeza que a fala se refere ao seu bom trabalho e sagacidade. $3^{\mathrm{a}}$ - E por último um golpista que ascendeu ao poder se sentirá atacado e poderá responder: Não é golpe! Impeachment está previsto na Constituição Federal de 1988!

Outro aspecto que deve ser levado em conta na comunicação é a redundância. Podendo ser vista como uma condução em que se percebe muita força para mover pequena mensagem, num processo fundado na quantidade e não na objetividade, não se trata apenas de palavras (escritas e faladas), mas até de letras conforme mostrou pesquisa recente que $a$ manutenção da primeira e da última letras da palavra e o comprimento da mesma, com alteração das letras intermediárias, continuava mantendo a possibilidade de leitura, pois a mente busca a manutenção do sentido pela apreensão da globalidade do texto. ${ }^{8}$

Não se pode deixar de refletir que a redundância pode decorrer de uma medição do ruído, explica-se, tendo em vista a consciência de que o ruído é um elemento real a ser considerado no processo de comunicação foi preciso desenvolver instrumentos técnicos para melhorar as condições do canal. Do ponto de vista da comunicação interpessoal a maneira de reduzir a interferência foi a fazer uma massificação do signo como estratégia importante para cravar no receptor a ideia que se quer transmitir.

Frise-se ainda que a redundância não significa a massificação/proliferação de uma mensagem que parte de várias fontes para vários destinos, ela pode estar em cada canal, mas nada tem a ver com a coincidência de mensagens que poderão ser vistas nos mais variados

\footnotetext{
${ }^{7}$ Ibidem. p. 20.

${ }^{8}$ PUGLIESI, 2009. p. 21.
} 
canais. A redundância só ocorre no mesmo canal, ao passo que a massificação é a proliferação de vários canais.

Existem uma série de exemplos presentes na História que ao serem transmitidos levam a mensagem de poder. É assim com o holocausto (força/violência usada contra os judeus), a tomada de Auschwitz pelo exercito vermelho (força/violência contra o nazismo), ou as bombas atômicas poder contra a URSS, pois contra o Japão foi violência. Com isso evidencia-se que apesar de canais diferentes a mensagem de poder de destruir está presente em todas elas, isso é proliferação e não redundância.

Além disso, é importante apresentar mais alguns conceitos que serão necessários ao presente trabalho. Nesta linha é importante os conceitos de paradigma e sintagma

\footnotetext{
Pode-se então considerar um paradigma como o conjunto de signos, com aspectos comuns e diferenciais que se encontram à nossa disposição para a sua utilização em determinadas comunicações específicas. $O$ seu aspecto comum indica essa comunicação específica, enquanto os aspectos diferenciais oferecem a possibilidade de uma significação determinada e não ambígua. $\mathrm{O}$ aspecto sintagmático indica as regras de combinação dos elementos desse paradigma, ou mesmo de paradigmas diferentes, para que a comunicação possa fazer sentido. ${ }^{9}$
}

Pode-se dizer que um paradigma é a percepção geral e comum de se ver determinada coisa, que poderá ser um objeto ou ainda um fenômeno como o poder, por exemplo. E na medida em que esse conjunto de signos passa a ser aceito, ele irá servir como elemento de verdade. No que se refere ao sintagma é possível defini-lo então como a forma de exteriorização do paradigma, e isso não pode ser visto de modo aleatório, de modo que as palavras precisam se articular para formar um conjunto amplo que pode ser uma frase ou oração.

$\mathrm{Na}$ citação surgiu o termo signo que é a composição entre o significante e o significado, sendo que o significante é como se fosse à imagem do som (manifestação fônica do signo). E o significado é o conteúdo semântico do signo. Exemplo: O signo carro relaciona-se a imagem acústica, ou sequencial de fonemas (significante), e ainda um conhecimento humano sobre o que representa aquela imagem acústica (significado).

Diz-se aqui que a mensagem muito trabalhada no incremento de detalhes é como uma taça de cristal do percurso da fábrica até a mesa de quem irá usa-la para beber vinho, ou seja, corre sempre o risco de não chegar íntegra ao seu destino, é preciso que a mensagem seja mais rústica, clara, direta como um copo de alumínio que com certeza chegará no máximo amassado, mas inteiro para ser usado.

\footnotetext{
${ }^{9}$ Ibidem. p. 22.
}

Rev. de Sociologia, Antropologia E Cultura Jurídica | e-ISSN: 2526-0251 | Goiânia| v. 5 | n. 1 | p. 23-42 | Jan/Jun. 2019 
Logo, quanto mais simples a mensagem maior será a chance de que ela realmente atinja a sua função. Porém, o simples fato de a mensagem chegar ao receptor não garante por si só que as partes estejam de fato se entendendo, pois existem diferentes representações, conotações, entonações, tempo, espaço, que são determinantes fundamentais para garantir o sucesso do processo, pois a linguagem que é fundamental para o sucesso de uma comunicação possui funções diversas

A função descritiva (indicativa, referencial) é aquela que mais se usa na linguagem humana. A linguagem pode descrever fatos, coisas e estados de coisas do mundo. Tudo se passa como se a cada palavra ou frase correspondesse algo de exterior que se pudesse apontar como seu referente, ou equivalente a ela. Por isso também se pode falar em função referencial. [...] A função injuntiva (conativa) tende a suscitar uma determinada ação ou resposta do receptor que é, então, o referente das mensagens. Pode tratar-se de uma ordem (imperativo) ou de um pedido (apelativo). A forma interrogativa também se pode considerar um caso particular da injunção, uma vez que se apela ao interlocutor para que este dê uma resposta à pergunta emitida (por vezes, incluso, resposta de natureza física. P. ex.: "Você poderia me dar licença?"; "Você seria capaz de finalizar essa tarefa?" etc.). Na sua generalidade, a função injuntiva não pertence apenas à linguagem humana, pois além de pertencer a animais, pode ainda ser demonstrada por símbolos não necessariamente conscientes e verbais, mas, também, físicos e posturais. ${ }^{10}$

No que se refere ao poder como relação o que fica evidente é que o poder liga-se a função injuntiva, ou seja, é a que mais se aplica. Todas as relações de poder têm como objetivo promover uma postura, ação, omissão, reação do destinatário da mensagem. Neste sentido o poder procura justamente isso uma postura de quem está na outra ponta da relação, fazendo-o, ou levando-o a emitir uma resposta verbal, física, ou postural.

A função expressiva (emotiva, auto-apresentativa) implica uma orientação para o emissor, que é, ele próprio, o referente das suas mensagens. Já nos animais inferiores ela é patente (grito, guincho), e pode estar na base da injunção de fuga para animais da mesma espécie. Na linguagem humana manifesta-se segundo Jakobson por interjeições, acentuações de voz ou efeitos irônicos. [...] A função fática tem por objetivo a manutenção do canal em boas condições. Ela é óbvia nas conversações telefônicas quando se pede para falar mais alto. Mas também é comum nas conversações normais, em situações de distração ou de maior ruído. Muitas conversas sobre temas banais, ou mesmo os cumprimentos do dia a dia, não têm senão o sentido de manter o canal de comunicação. Alguns animais que vivem escondidos em florestas fazem vocalizações periódicas com o objetivo aparente de se avisarem mutuamente da sua presença. Cumprem então a função fática da linguagem. O primeiro linguajar das crianças parece igualmente cumprir esta função. [...] a função poética (ou estética), intimamente ligada às mensagens independentemente do seu significado. De fato, o que transforma um conjunto de frases numa poesia é essa função que joga com o ritmo, consonâncias e dissonâncias, semelhanças e contrastes, numa palavra, com a música das palavras. [...]. A função metalinguística, que pressupõe significados e sentidos, torna-se assim

${ }^{10}$ PUGLIESI, 2009. p. 28. 
complexa, e seria redutor referi-la apenas à equivalência de signos verbais. De fato, tanto o significado como o sentido das palavras se podem modificar em cada contexto da relação. O contexto é definido, quer pelo ambiente em que as pessoas estão inseridas (casa, local de trabalho, local de diversão pública, local de culto etc.), quer pela comunicação não verbal (tom, ritmo e intensidade de voz; postura, olhar; mímica facial, gestos). ${ }^{11}$

Com tais demonstrações sobre as várias funções da linguagem ressalta-se que na verdade o processo relacional, e comunicativo apresenta grandes chances de gerar mais divergência do que convergências, ao contrário do que pensa Jürgen Habermas, por exemplo, para quem a linguagem é fruto de uma interação pessoal e que tende ao consenso e a racionalidade ${ }^{12}$.

Em síntese é importante expressar que a comunicação de poder somente será eficaz quando se consegue superar, essa possibilidade de desencontro entre a mensagem enviada e a mensagem recebida. $\mathrm{O}$ poder somente será comunicado na medida em que envia a mensagem e gera a reação desejada no destinatário, quando isso não ocorrer teremos a desconsideração da mensagem de poder e consequente inércia do destinatário.

\section{A análise de Jessé de Souza: Mídia e poder}

O Brasil viveu um fato histórico concreto que foi o golpe de estado de 2016. Neste sentido, uma publicação do professor Jessé de Souza apresenta uma profunda análise sobre o tema do golpe de 2016, de modo que A Radiografia do Golpe $e^{13}$ é um título que faz jus a análise realizada em tal obra.

A referida obra é importante não somente pelo fato de apresentar estudo profundo sobre o golpe de estado de 2016, mas também porque analisa o processo de comunicação por meio do qual o golpe foi efetivado com apoio central da mídia nacional, ou seja, a mídia comunicou para realiza-lo com o fim de satisfazer os anseios do criptogoverno ${ }^{14}$.

\footnotetext{
${ }^{11}$ PUGLIESI, 2009. p. 29/31.

12 HABERMAS, 1987 apud PUGLIESI, 2009. p. 31.

${ }^{13}$ SOUZA, Jessé de. A radiografia do Golpe: entenda como e por que você foi enganado. Rio de Janeiro: LeYa, 2016.

${ }^{14} \mathrm{O}$ autor define o quem tem o poder de governar "com base no critério de diferentes graus de visibilidade, três faixas que chamarei de poder emergente ou público, que é a do governo propriamente dito, a faixa do poder semi-submerso ou semipúblico, que é a do subgoverno, e a faixa do poder submerso, oculto ou invisível, que não tem ainda nome (mas existe, e como!) e poderia ser chamada de criptogoverno". BOBBIO, Norberto. As ideologias e o poder em crise. Tradução de João Ferreira; Revisão técnica Gilson César Cardoso. 4 ed. Brasília: Editora Universidade de Brasília, 1999. p. 204.
} 
Pondera Jessé de Souza que o que vivemos no Brasil é evidentemente um jogo de poder no qual o grande objetivo seria garantir que a maioria seja excluída para que a minoria possa expropriar a riqueza nacional sem que seja preciso violência. Logo,

\begin{abstract}
Ninguém se deixa explorar de modo direto e violento sem reação. A possibilidade de debelar a reação com mais violência sempre se revelou muito custosa e, crescentemente com o avanço da história, de eficácia apenas a curto prazo. No mundo moderno, quem quiser se apropriar, por meio de instrumentos de mercado e de Estado, da riqueza e do produto do trabalho alheio tem, antes, de convencer os espoliados de que a dominação que os explora e subordina é para seu próprio bem. Esse trabalho de mostrar aos dominados que sua própria dominação, que os explora e subordina, é boa para eles mesmos não é fácil. E por conta disso a elite do dinheiro, que é a elite que retira do bolso da sociedade o produto do trabalho de todos para pô-lo no próprio bolso, precisa de outras elites para ajudá-la a fazer esse trabalho. Nesse sentido, é incorreto falar em "elite" de maneira abstrata, pelo menos nas sociedades capitalistas modernas. A elite que "manda" é sempre a elite do dinheiro, pelo simples fato de que ela pode comprar todas as outras elites, que, por conta disso, lhe são subordinadas. Como a exploração material e econômica nunca se dá sozinha, mas tem que, antes, colonizar a aprisionar o espírito do explorado, a primeira elite a ser comprada é a intelectual. As elites do dinheiro e do poder precisaram, em todas as épocas, convencer a imensa maioria dominada e explorada de que seus privilégios são merecidos e justos. ${ }^{15}$
\end{abstract}

A definição de elite como sendo a elite do dinheiro, cite-se entrevista de um banqueiro ${ }^{16}$ que opinou sobre a permanência, ou não de Dilma Vana Roussef na Presidência da República ele na verdade é o que Jessé de Souza descreve como pertencente a elite, ou seja, aquele que tem o dinheiro, um membro do sistema financeiro nacional.

Apesar de ser a elite do dinheiro a verdadeira e única elite por ser muito reduzida ela não consegue exercer poder sozinha, e daí a necessidade de comprar outros seguimentos sociais para exercer poder. Neste sentido, é notório que a elite exerce poder por intermédio da classe média, que é visceral, raivosa, fascista, e numerosa.

E para exercer o poder nada mais adequado à elite do que utilizar-se da mídia para que isso seja exercido sem que o destinatário da mensagem de poder perceba o enredo de dominação em que foi inserido. E o papel do convencimento da maioria no passado era da religião e agora pertence a ciência, aos intelectuais. ${ }^{17}$

\footnotetext{
${ }^{15}$ SOUZA, 2016. p. 19/20.

${ }^{16}$ VEJA. Roberto Setubal defende a permanência de Dilma Rousseff na presidência. Da redação. Disponível em: <http://veja.abril.com.br/noticia/brasil/roberto-setubal/> Acesso em 07 de OUT. de 2015.
}

17 SOUZA, 2016. 
Chama a atenção também o raciocínio de que na política é preciso que o agente esconda os reais interesses que são aumentar o capital econômico e político e garantir a permanência no poder. Boa parte da farsa cotidiana da atividade política advém dessa necessidade - entre a mentira aberta e o silenciamento -, existente em todas as outras atividades da vida. ${ }^{18}$

Se por um lado na política deve-se transitar entre a mentira e o silêncio na economia é diferente, aqui é sagaz vangloriar seus feitos em busca do lucro, não há porque esconder seus reais objetivos, muito se trabalhou para justificar o direito de lucrar das classes econômicas dominantes.

Pensadores de grande prestígio e influência como Max Weber contribuíram de modo
decisivo para que uma aura de prestígio para a atividade da elite econômica fosse
possível. Weber foi o pai, ou pelo menos o autor de mais prestígio, de um
pensamento que fundou um corte "moral" entre a atividade econômica pré-
capitalista e a capitalista propriamente dita. A famosa distinção entre um
"capitalismo aventureiro", supostamente pré-moderno, e um "capitalismo sóbrio",
sob a égide da temperança dos afetos protestante, hoje na cabeça de todos, teve na
sua pena a melhor expressão. A ideia aqui é separar uma atividade econômica
supostamente sem planejamento e sem cálculo de longo prazo - um "capitalismo
pirata" baseado em lucros altíssimos, mas inconstantes e arriscados - do lucro
cotidiano e metódico. Apenas este último tipo de capitalismo mereceria o nome de
"racional", uma vez que baseado no controle dos afetos e no raciocínio prospectivo,
de modo a garantir sua continuidade infinita. Todas as guerras modernas e
contemporâneas para controlar matérias-primas chaves de países mais frágeis
militarmente provam o contrário da tese weberiana no que se refere a esse assunto.
O capitalismo da violência e do "butim" apenas se aperfeiçoou de lá para cá. A
guerra do Iraque, apenas para citar um exemplo, comandada pelo interesse de meia
dúzia de indústrias petrolíferas, matou milhões com base em mentiras comprovadas
e tornou instável uma região inteira com consequências que se arrastam até os dias
de hoje. O "corte moral" do capitalismo moderno é falso. Tudo mostra a
continuidade histórica da rapina colonial. Mas continuamos ingenuamente a
acreditar na excepcionalidade moral do capitalismo contemporâneo. Isso mostra a
extraordinária resiliência das justificações da elite do dinheiro e de seu poder de
pautar o que acredita ser verdadeiro ou falso. ${ }^{19}$

No Brasil evidente que isso não se mostra diferente, a rapina é o grande pano de fundo da derrubada da uma presidente legitimamente eleita. Uma rapinagem tão estúpida que sequer chega a construir um projeto, ela é sempre pensada no curto prazo, a elite nacional tem em sua mente rapinar hoje, agora.

Ademais, como tantos podem ser iludidos por tão poucos? Reafirmando que a elite brasileira também contou com a ciência, com a elite intelectual para justificação de sua posição e ações. A justificação ocorre por meio de instrumentos políticos e sociais, e um deles é a criação deste mito nacional que é uma narrativa acerca do lugar de onde se vem, quem se

${ }^{18}$ SOUZA, 2016.

${ }^{19}$ Ibidem. p. 23.

Rev. de Sociologia, Antropologia E Cultura Jurídica | e-ISSN: 2526-0251 | Goiânia | v. 5 | n. 1 | p. 23-42 | Jan/Jun. 2019 
é e para onde se vai. É necessário conhecer o mito nacional para saber como as pessoas se veem na relação com os outros. ${ }^{20}$

Neste sentido Jessé de Souza destaca o papel de Gilberto Freyre e Sergio Buarque de Holanda como aqueles que contribuíram sobremaneira para a construção do mito nacional brasileiro. Uma missão complexa dada a baixa autoestima do povo brasileiro, ou seja, como tornar o mito criado agradável à sociedade.

Freyre percebeu a importância de incorporar ao mito brasileiro uma crítica ao modelo social americano que permitisse a percepção de "virtudes brasileiras" de modo que uma auto-percepção positiva do país fosse possível. Repetindo o que dissemos antes: a questão aqui é prática, e não teórica. Não se tratava da opção entre verdadeiro ou falso, como na ciência. Tratava-se de conferir uma possibilidade de orgulho nacional que por sua vez permitisse cimentar uma solidariedade nacional, que o país - então em profunda transformação sob Getúlio Vargas - tanto necessitava. Freyre descobriu isso - daí sua genialidade - na noção que permitia transformar o mulato de lata de lixo da história em virtude nacional, precisamente em oposição aos EUA. Para isso Freyre constrói a história do Brasil como prolongamento de Portugal representando "valores culturais" em oposição aos EUA. A suposta cultura luso-brasileira seria a cultura da mistura e, mais ainda, do "congraçamento entre as raças e culturas" que a comporiam, Ficava clara a oposição com a segregação racial americana - à época ainda muito maior que hoje em dia. Essa ideia permitia que Freyre usasse o "calcanhar de Aquiles" da sociedade americana, a sua segregação racial aberta e legalizada, para construir uma suposta virtude brasileira por oposição ao racismo americano. ${ }^{21}$

Segundo a compreensão de Jessé de Souza a construção do mito nacional brasileiro se dera com o trabalho de Gilberto Freyre e aponta que devido essas bases fundadas por ele é que o brasileiro é hospitaleiro, abertos, emotivos, sexualizados. ${ }^{22}$ Mas o papel de avançar na construção do mito nacional relegaria a Sergio Buarque de Holanda aproveitar tais bases para cravar o mito nacional brasileiro na obra As raízes do Brasil

Afinal, vem de Buarque a interpretação dominante até hoje do nosso mito nacional. Todas as ideias centrais de Buarque vêm de Freyre, inclusive a noção central de homem cordial. Ou seja, o intelectual tido como pioneiro da ciência social "séria" e "científica" entre nós - ainda lido e debatido em todas as nossas universidades como referencia fundamental - retira acriticamente os elementos de um mito, sem compromisso com a verdade, para fundar a ciência social até hoje dominante no Brasil. Belo começo para uma "ciência" rigorosa. O que confere toda a atualidade deste acerto de contas com Buarque é que ele não apenas engole o racismo científico sem crítica alguma, mas interpreta o nosso vício como uma tendência inata à corrupção. A corrupção começa a se tornar com ele uma espécie de jabuticaba cultural brasileira. Ao definir o homem cordial, literalmente o "homem do coração", como o protótipo do brasileiro de todas as classes, retirando dele as ambiguidades freyrianas da emotividade, como proximidade e abertura cultural, e ao defini-lo

\footnotetext{
${ }^{20}$ SOUZA, 2016. p. 28.

${ }^{21}$ FREYRE, 1991 apud SOUZA, 2016. p. 31.

22 Ibidem. p. 32.
} 
apenas negativamente, Buarque cria os fundamentos da ciência conservadora do Brasil moderno que se vende com ares de crítica. Essa é a marca central da ciência social dominante no Brasil. Ela é produto do que há de mais preconceituoso, conservador e superficial. Buarque apenas repete o racismo científico nunca discutido dessas noções que parecem críticas, quando nada mais são que produtos do pior racismo e preconceito. Quando Buarque diz que o brasileiro é o homem cordial, prisioneiro das próprias emoções, ele supõe que exista um outro tipo de gente que teria se libertado dessa prisão. É aqui que mora todo o racismo, toda a ingenuidade e toda a admiração basbaque do brasileiro com o complexo de vira-lata em relação ao estrangeiro visto como superior. Esse estrangeiro superior e livre da prisão dos afetos animais é para ele (e para $90 \%$ dos brasileiros ingênuos até hoje) o americano percebido como racional e incorruptível. O raciocínio básico de Buarque, em resumo, é o seguinte: o homem emotivo brasileiro (como se tal generalização fosse possível), ao dividir o mundo entre amigos e inimigos, se afasta da lei e da noção de cidadania, corrompendo o exercício impessoal e republicano não só da política, mas também do mercado. ${ }^{23}$

Como se sabe a jabuticaba é uma fruta genuinamente brasileira e a corrupção então passa a ser uma característica do Brasil. E de fato isso vira um mito nacional, ao ponto de se ouvir o povo por vezes dizer: No Japão um político se suicidou porque foi pego desviando recursos públicos! Pode-se trocar o Japão por qualquer outro país, afinal são muitos, mas ressalta-se que o suicida no caso não é um exemplo de honestidade.

Tal mito nacional será fundamental para a construção de muitos discursos favoráveis ao golpe de estado de 2016. Mas quando Jessé de Souza apresenta essa construção pela qual passou o mito nacional de que o brasileiro é corrupto, tem a corrupção em suas veias, será a base importante para entender como a elite do dinheiro utilizou da mídia para exercer poder e conseguir consagrar a queda de uma presidente legitimamente eleita. ${ }^{24}$

Explicado o mito nacional Jessé de Souza parte para demonstrar como os movimentos sociais de 2013, ou os protestos de 2013 foram direcionados pela mídia para que as pautas municipais pudessem ser federalizadas e com isso conseguir uma massa que pudesse dar um mínimo de apoio social para canalizar os protestos em direção a Presidente Dilma Vana Rousseff. ${ }^{25}$

Então, o que a mídia passou a fazer para lograr esse êxito foi acompanhado de modo meticuloso durante todo o mês de junho de 2013 e com isso percebeu-se a total alteração do posicionamento da Rede Globo que fez isso principalmente pelo Jornal Nacional

Se tomarmos o Jornal Nacional, da Rede Globo, uma espécie de porta voz da reação conservadora extraparlamentar que se forma nas ruas do país e que só se conclui com o impeachment da presidente eleita, podemos acompanhar passo a passo esse processo. O que se chamou mais tarde de "jornadas de junho" começou como manifestação de alguns milhares de jovens contra o aumento das passagens de

\footnotetext{
${ }^{23}$ HOLANDA, 2004 apud SOUZA, 2016. p. 36.

${ }^{24}$ SOUZA, 2016.

25 SOUZA, 2016.
} 
ônibus em diversas capitais brasileiras, com epicentro em São Paulo. No dia 10 de junho de 2013, aconteceu a primeira referência do Jornal Nacional às manifestações. Como toda referência inicial, ela foi negativa, enfatizando o "tumulto", o prejuízo ao trânsito e o incomodo à população. ${ }^{26}$

De forma que inicialmente os protestos eram exclusivamente contra o aumento da tarifa de transporte público como se viu, valendo lembrar que a competência do transporte público é dos municípios e não do governo federal. Pontua Jesse de Souza que por volta do dia 13 de junho o Jornal Nacional começa a mencionar o combate a Proposta de Emenda Constitucional n. 37 (PEC 37) como sendo também uma das demandas vindas das ruas. Por tal proposta a atividade investigativa deveria ser responsabilidade exclusiva das polícias retirando do Ministério Publico essa prerrogativa.

Paralelamente o Jornal Nacional começava a divulgar pesquisas sobre a popularidade da Presidente Dilma Vana Rousseff em que se percebia uma queda de $8 \%$ na popularidade segundo a pesquisa

\begin{abstract}
Apesar de a queda inicial ter sido apenas moderada, percebia-se claramente que os protestos podiam ser canalizados para atingir a presidenta. O jornal Nacional cerrou fileiras contra a presidenta e seu governo. Os temas que se tornariam clássicos mais tarde se constituíram aqui. A bandeira da antipolítica e antipartidos surgiu. Inflação e custo de vida se tornaram bandeiras e substituíram a passagem de ônibus. Entraram com toda força o ataque à PEC 37 e o tema cada vez mais importante da corrupção. $^{27}$
\end{abstract}

As bases da teoria de Sergio Buarque de Holanda passaram a ser utilizadas num discurso contra a corrupção geral, natural, histórica, e por que não dizer genética do brasileiro. Essa guinada de posicionamento do Jornal Nacional agora implacável perseguidor de políticos corruptos conduziria o Brasil a mais um golpe de estado para sua história concreta.

A perícia da comunicação promovida pelo Jornal Nacional nestes eventos era um fato a se destacar, pois apoiavam a classe média que agora já saia às ruas com suas camisas da seleção brasileira de futebol e "sem ligação político partidária" e ao mesmo tempo em que marginalizava os adeptos do movimento anarquista Black Bloc.

O Jornal Nacional deu cobertura à matéria do New York Times sobre as manifestações, que as interpretava como reclamação contra os "serviços públicos precários", significando que a maioria da população não estaria satisfeita com as promessas petistas. A ala direitista da classe média, que passa a ser o núcleo central do movimento, tendia a ser percebida como "o povo" chamado nas ruas. Os

${ }^{26}$ Ibidem. p. 89.

${ }^{27}$ Ibidem. p. 91. 
"baderneiros" eram agora agentes infiltrados no movimento democrático e pacífico. $^{28}$

O governo federal tendo em vista o acirramento das tensões sociais realizou em Brasília uma reunião entre com os manifestantes, porém o que se notou foi uma comunicação completamente prejudicada pelo ruído promovido propositalmente pela mídia em especial o Jornal Nacional.

Uma repórter do jornal $O$ Globo perguntou ao líder do Movimento Passe Livre, que
pretendia encerrar o movimento, já que o aumento das passagens fora revogado, se
as "outras pautas", como a PEC 37 e o combate à corrupção, não merecem também
continuar. O líder respondeu que essas jamais foram pautas do movimento e se
declarou contra a hostilização de partidos políticos. A manifestação perdia seu
sentido popular e reivindicatório e se tornava uma "festa popular" contra a
corrupção e a ladroagem na política, o que se tornava definitivamente a bandeira
central. O PT e os manifestantes da esquerda foram hostilizados. Aqueles ligados a
partidos políticos foram expulsos. ${ }^{29}$

Com a resposta do representante do movimento fica bastante claro o que era pauta dos protestos e o que era pauta da Rede Globo. Porém, apesar disso o golpe se efetivou em 2016 com a derrubada da Presidente Dilma Vana Rousseff e a ascensão de Michel Temer, um dos Capitães do Golpe de 2016.

Concorda-se com a afirmação de Jessé de Souza que todos os golpes que se deram tem por objetivo garantir mais dinheiro para poucos ${ }^{30}$. No caso brasileiro basta ver a sequencia do golpe de 2016 em que o governo golpista de Michel Temer que conseguiu aprovação da Emenda Constitucional 95 - EC 95 que limitação nos investimentos públicos (Previdência, Saúde, Educação, Transporte, etc.).

Bem verdade é que o impeachment ocorreu justamente para que a elite do dinheiro pudesse conseguir mais dinheiro para si, ou seja, o objetivo não era retirar um governo e sim aprovar as medidas introduzidas pela EC 95.

Até se poderia concordar com essa proposta se não se soubesse que em 2015, por exemplo, o governo federal gastou R $\$ 962$ bilhões com juros e amortizações da dívida pública, o que representou $42,43 \%$ de todo o orçamento efetivamente executado no ano. Essa quantia corresponde a 10 vezes o que foi destinado à Saúde, 11 vezes aos gastos com Educação, ou quase o dobro dos gastos com a Previdência Social basta analisar o gráfico a seguir:

${ }^{28}$ SOUZA, 2016. p. 92.

${ }^{29}$ Ibidem. p. 93

${ }^{30}$ Ibidem. 


\section{Orçamento Geral da União (Executado em 2015) -} Total $=$ R\$ 2,268 trilhões

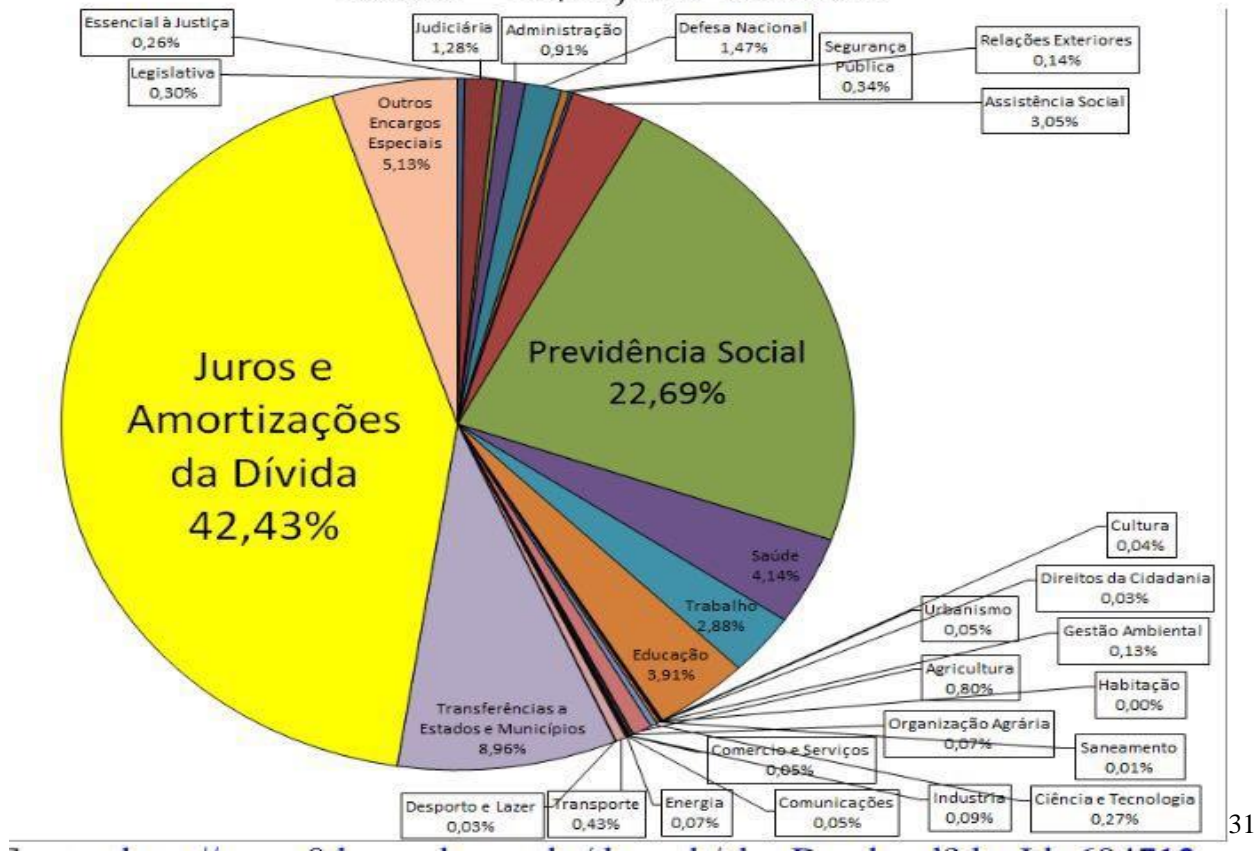

O criptogoverno ${ }^{32}$, a elite do dinheiro ${ }^{33}$, está inserida na fatia em amarelo $(42,43 \%)$, e a mídia não abre espaço para que se possa esclarecer a população sobre essa mazela brasileira. A mídia comprada pelo criptogoverno não se propõe a fomentar o debate de que não é civilizado gastar 10 vezes mais com juros do que com a saúde pública.

Ademais, fica evidente porque o governo golpista de Michel Temer tentou e o governo acéfalo dos bolsonaros tentará realizar investida contra a previdência social, pois diminuir o orçamento da previdência social representa maior capacidade de aumentar a fatia destinada ao sistema financeiro com o pagamento dos juros.

Mais angustiante ainda é saber que desde 1988 esta prevista a realização da Auditoria na Dívida Externa brasileira e que apesar da previsão do artigo 26 do Ato das Disposições Constitucionais Transitórias até hoje isso não foi feito. Geralmente o discurso é o de que os servidores públicos são os responsáveis pelos impactos orçamentários, ou que a corrupção na

${ }^{31}$ FATTORELLI, Maria Lúcia. Sobraram R 480 bilhões no caixa do governo em 2015. Disponível em: <http://www.auditoriacidada.org.br/blog/2016/07/25/sobraram-r-480-bilhoes-no-caixa-do-governo-em-2015/> Acesso em: 23 de NOV. de 2016. sp.

${ }^{32}$ BOBBIO, 1999.

${ }^{33}$ SOUZA, 2016. 
Petrobrás é a causadora da crise econômica, e nada dizem sobre a questão da Divida Pública que hoje consome mais de $40 \%$ do orçamento anual executado.

O que se vê então é que a mídia comunica com a massa para garantir a aceitação de sua pauta que por sua vez é determinada pela elite do dinheiro (criptogoverno) para garantir que a população aceite de forma passiva a expropriação do produto do trabalho social para as mãos de um pequeno número de pessoas.

Lembrando que a alegação para a aprovação do impeachment foi a de cometimento de crime de responsabilidade pela presidente Dilma Vana Rousseff. Contestando tal tese pontua Aldo Fornazieri

\begin{abstract}
O depoimento do professor Ricardo Lodi no Senado Federal, na condição de informante, nesses últimos dias do julgamento da presidente Dilma, reduziu a escombros a tese de que Dilma cometeu crime de responsabilidade. Lodi mostrou cabalmente que: 1) as chamadas "pedaladas fiscais", que não são um conceito jurídico estabelecido em nenhum documento, não constituem crime de responsabilidade, pois não há nenhum prazo legalmente estabelecido para que o governo salde os breves débitos junto aos bancos públicos. O governo Dilma saldou esses débitos, no máximo, em quatro meses, o que está dentro de um limite de razoabilidade; 2) em 2015, o governo Dilma cumpriu a meta fiscal, redefinida pelo Congresso no final do ano. Mesmo que o governo não tivesse cumprido a meta fiscal não seria crime de responsabilidade, pois as contingências da economia podem impedir que um governo cumpra a meta fiscal. $O$ que constitui crime de responsabilidade é o não cumprimento da Lei Orçamentária, coisa de que Dilma não é acusada; 3) os decretos suplementares não constituem crime de responsabilidade, pois há uma compatibilidade entre decretos complementares e contingenciamento do orçamento. Assim, os decretos de suplementação não elevam execução de despesa pública; 4) ademais, quanto a autoria dos decretos, eles são definidos por lei e não são de responsabilidade direta da presidente. Os próprios técnicos do Senado haviam concluído que Dilma não é responsável pelos decretos. ${ }^{34}$
\end{abstract}

Diga-se ainda que a Presidente Dilma Vana Rousseff foi derrubada sem sequer figurar na lista de investigados pela operação Lava Jato, eis o poder que fora exercido de uma tal maneira com a comunicação de uma mensagem manipulada e fundada num mito de combate a corrupção.

E não se deve ter receio em afirmar que o que ocorreu na política nacional em 2016 foi um golpe de estado sem a menor sombra de dúvida, ainda que alguns digam que o impeachment esta previsto, e que a lei foi respeitada. $\mathrm{O}$ fato é que existem dois tipos que defendem o golpe de 2016, o primeiro são os enganadores e o segundo os enganados.

Não resta dúvida de que os golpes contemporâneos irão ocorrer com formas aparentemente democráticas e legais de modo que não se faz mais golpe como antigamente

\footnotetext{
34 FORNAZIERI, Aldo. Impeachment político é golpe. Disponível em: <http://jornalggn.com.bbmr/noticia/impeachment-politico-e-golpe-por-aldo-fornazieri> Acesso em: 29 de AGO. de 2016. sp.
} 
com a utilização da força militar, agora como bem pondera Michel Foucault ${ }^{35}$ os instrumentos de controle e poder se tornaram muito mais potentes, um exemplo disso é o próprio Jornal Nacional da Rede Globo e o procedimento do impeachment traçado em conjunto com Legislativo e Judiciário, tudo para dar ares de democracia e legalidade a uma violenta derrubada de uma presidente eleita pelo voto popular.

\section{O papel do simbólico na comunicação.}

Neste sentido a função da mídia em especial a Rede Globo com seu Jornal Nacional teve o papel crucial no sentido de comunicar com o público desejado de forma a retirar qualquer percepção do povo de que o golpe de 2016 tratava-se de uma violência, ou seja, era preciso subtrair do expectador sensibilidade. O que a mídia fez foi justamente possibilitar uma hanseníase no corpo do Leviatã de modo a lhe retirar o tato e isso para Pierre Bourdieu é

O poder simbólico como poder de constituir o dado pela enunciação, de fazer ver e fazer crer, de confirmar ou de transformar a visão do mundo e, deste modo, a ação sobre o mundo, portanto o mundo; poder quase mágico que permite obter o equivalente daquilo que é obtido pela força (física ou econômica), graças ao efeito específico de mobilização, só se exerce se for reconhecido, quer dizer, ignorado como arbitrário. Isto significa que o poder simbólico não reside nos "sistemas simbólicos" em forma de uma "illocutionary force" mas que se define numa relação determinada - e por meio desta - entre os que exercem o poder e os que lhe estão sujeitos, quer dizer, isto é, na própria estrutura do campo em que se produz e se reproduz a crença. O que faz o poder das palavras e das palavras de ordem, poder de manter a ordem ou de a subverter, é a crença na legitimidade das palavras e daquele que as pronuncia, crença cuja produção não é da competência das palavras. ${ }^{36}$

Aqui no caso brasileiro conforme percebemos ao longo do tempo um visível processo de substituição da violência quase que natural nos golpes por uma estrutura mais apurada. Logicamente que com o golpe militar de 1964 isso não foi feito, pois os militares não resistiram e de fato utilizaram de violência direta para a tomada do poder, mas agora no golpe de 2016 o que se viu foi um sistema muito bem lubrificado em que o capital financeiro exerceu seu poder por meio das instituições Câmara, Senado, Judiciário, Ordem dos Advogados do Brasil, e com a manipulação da mídia o processo não passou aos olhos do povo como sendo arbitrário, apesar de sê-lo.

O poder simbólico, poder subordinado, é uma forma transformada, quer dizer, irreconhecível, transfigurada e legitimada, das outras formas de poder: só se pode

\footnotetext{
${ }^{35}$ FOUCAULT, 2012.

${ }^{36}$ BOURDIEU, Pierre. O poder simbólico. Tradução de Fernando Tomaz. Rio de Janeiro: Editora Bertrand Brasil S.A., 1989. p. 14.
}

Rev. de Sociologia, Antropologia E Cultura Jurídica | e-ISSN: 2526-0251 | Goiânia| v. 5 | n. 1 | p. 23-42 | Jan/Jun. 2019 
passar para além da alternativa dos modelos energéticos que descrevem as relações sociais como relações de força e dos modelos cibernéticos que fazem delas relações de comunicação, na condição de se descreverem as leis de transformação que regem a transmutação das diferentes espécies de capital em capital simbólico e, em especial, o trabalho de dissimulação e de transfiguração (numa palavra, de eufemização) que garante uma verdadeira transubstanciação das relações de força fazendo ignorar-reconhecer a violência que elas encerram objetivamente e transformando-as assim em poder simbólico, capaz de produzir efeitos reais sem dispêndio aparente de energia. ${ }^{37}$

O poder simbólico trabalha com o processo de eufemização conforme a menção de Pierre Bourdieu, ou seja, a atuação da mídia para que a elite do dinheiro alcance seus objetivos é comunicar com a sociedade de modo à amezinhar conceitos como o saque aos cofres públicos por desvio de função, ou golpe de estado por impeachment, condutas fascistas e ilegais de certos juízes por combate aos corruptos.

\section{Conclusão}

Ante aos apontamentos e análise traçados acima chegamos a conclusão de que existe uma diferença fundamental entre o poder e violência. Pode ser que o uso da violência leve ao poder, mas não é uma garantia. Neste sentido o processo de comunicação é fundamental para de modo sutil fazer com que o poder seja enviado em forma de mensagem e isso gere efeitos os efeitos planejados.

O processo de comunicação de poder faz com que nos distanciemos daquela visão realista de Sancho Pança e nos aproximemos da visão idealizada de Dom Quixote. Na medida em que o receptor de uma mensagem que comunica poder nos aproxima da forma de enxergar o mundo de Dom Quixote o poder esta sendo exercido sobre ele e o levará a moldar seu comportamento, atos, pensamentos.

Daí a importância de instrumentos capazes de transmitir mensagens de poder, pois como se sabe o poder não é um substantivo, não é concreto, ele se aproxima muito mais de ser verbo, ou ação, e justamente por isso seu exercício conta necessariamente com a capacidade de moldar os atos a partir de um entendimento construído pela capacidade de êxito do emissor no processo de comunicação.

Outra forma de moldar o comportamento e as ações do receptor da mensagem que não se funde no convencimento via processo de comunicação não será poder, será apenas violência. O golpe de 2016 é um exemplo de poder, pois construiu um argumento e atingiu

${ }^{37}$ Ibidem. p. 15.

Rev. de Sociologia, Antropologia E Cultura Jurídica | e-ISSN: 2526-0251 | Goiânia| v. 5 | n. 1 | p. 23-42 | Jan/Jun. 2019 
uma finalidade sem que isso se desse por meio de violência física. Ressalte-se que a burguesia do dinheiro (criptogoverno), sequer apareceu apesar de idealizar e implementar o argumento.

Dessa forma, no caso a mídia possui elevada possibilidade de replicar um argumento seu ou de terceiros que possibilitará moldurar ações do receptor da mensagem sem que este se sinta vítima de violência, mas na realidade está sendo conduzido pela mensagem de poder. Bem verdade que a mensagem de poder não possui uma única forma, pois ela poderá se dar pela escrita, fala, expressão da arte, gestos, ações, etc. Enfim uma capacidade de multiplicar a forma idealizada com que Dom Quixote analisava as coisas e situações.

O poder somente será exercido sobre o receptor na medida em que o emissor da mensagem quando o emissor lograr êxito em que o receptor acolha o significante e formule o significado que interessa ao objetivo do emissor.

Por isso o golpe de 2016 é exemplo claro de sucesso deste processo de comunicação de poder, pois a elite nacional elaborou uma mensagem e com o apoio da mídia levou a mensagem de que a presidente (significante) deveria ser deposta por ter cometido crime de responsabilidade (significado). E a elite teve sucesso nesse processo de comunicação de poder.

\section{Referências}

BOBBIO, Norberto. As ideologias e o poder em crise. Tradução de João Ferreira; Revisão técnica Gilson César Cardoso. 4 ed. Brasília: Editora Universidade de Brasília, 1999.

BOURDIEU, Pierre. O poder simbólico. Tradução de Fernando Tomaz. Rio de Janeiro: Editora Bertrand Brasil S.A., 1989.

CERVANTES, Miguel de. Dom Quixote de la Mancha. Tradução e Notas Ernani Ssó. Volume 1 Introdução de Jonh Rutherford. Volume 2 Posfácios de Jorge Luis Borges e Ricardo Piglia. São Paulo: Companhia das Letras, 2012.

FATTORELLI, Maria Lúcia. Sobraram R\$ 480 bilhões no caixa do governo em 2015. Disponível em: <http://www.auditoriacidada.org.br/blog/2016/07/25/sobraram-r-480-bilhoesno-caixa-do-governo-em-2015/> Acesso em: 23 de NOV. de 2016. sp.

FORNAZIERI, Aldo. Impeachment político é golpe. Disponível em: <http://jornalggn.com.br/noticia/impeachment-politico-e-golpe-por-aldo-fornazieri> Acesso em: 29 de AGO. de 2016. 
FOUCAULT, Michel. Microfísica do Poder. Organização, Introdução e revisão técnica de Roberto Machado. 25 ed. São Paulo: Graal, 2012.

PUGLIESI, Marcio. Teoria do Direito. 2 ed. São Paulo: Saraiva, 2009.

SOUZA, Jessé. A radiografia do Golpe: Entenda como e por que você foi enganado. Rio de Janeiro: Editora Leya, 2016.

VEJA. Roberto Setubal defende a permanência de Dilma Rousseff na presidência. Da redação. Disponível em: <http://veja.abril.com.br/noticia/brasil/roberto-setubal/> Acesso em 07 de OUT. de 2015. 